\title{
LOST IN IMPLEMENTATION: EU LAW APPLICATION IN ALBANIAN LEGAL SYSTEM
}

\author{
Bojana Hajdini, PhD. \\ bhajdini@beder.edu.al \\ Gentjan Skara, LL.M. \\ gskara@beder.edu.al \\ Department of Law, Kolegji Universitar "Bedër", Tirana, Albania
}

(Received February 2017; Accepted May 2017)

\begin{abstract}
Considering the growing importance of the researchers in the area of Europeanization in the candidate countries, the purpose of this paper is to analyse whether, and to what extent EU as a legal normative power has influenced Albania to approximate existing and future legislation and to ensure proper implementation. The paper argues that the Europeanization process is pushing Albania toward greater convergence with EU acquis by developing a modern legal framework. However, the paper points out that weak implementation has hampered the application of EU law in Albania due to: a) weak bureaucracy or uneven distribution of human capacities; b) the lack of an established practice of consultation with interest groups on specific draft legislation, and c) the inability to put in sound planning mechanisms and to carry out a realistic assessment. The paper concludes that effective adjustment of Albanian legal system with EU norms requires cooperation between different actors involved in the approximation and implementation process.
\end{abstract}

Keywords: EU; Albania legal system; EU Acquis; Approximation; Implementation

\section{Introduction}

The Europeanization process has been considered as the most effective tool of the EU in spreading democracy, the rule of law, fundamental freedoms and other values on which the EU is founded. Defined as a process of penetration of European values, principles, ideas, structures, and norms into domestic level of member states or candidate countries (Ladrech, 1994; Börzel, 1999; Green Cowles, Caporaso, Risse, 2001), Europeanization has become a buzzword in Western Balkan countries (Sedelmeier, 2014).

Since the fall of communism, the Albanian legal system has been subject to substantive changes, mainly for two important reasons. The first reason is related to the political, economic and social reforms introduced by the Albanian government at the beginning of the 1990s (Bideleux, Jeffries, 2007); whereas the second reason is related to the external influence of International Organizations, especially the Council of Europe and the European Union. By orientating its foreign policy toward these organisations, Albanian government has adjusted its domestic 


\section{JOURNAL OF LEGAL STUDIES}

"Vasile Goldiș" Western University of Arad

legislation to compliance with the requirements of these organisations to the maximum possible extent. Both these factors have played an important role in moving Albanian legal system toward European best practices.

Due to the scope of this article, the paper will be focused only on the influence of EU norms on Albanian legal system. The paper seeks to shed light on the role of EU as a normative legal power based on the export of the EU acquis and how effective has been Albania in absorbing the EU acquis. It argues that the Europeanization process is pushing Albania towards greater convergence with EU acquis through developing a modern legal framework. However, the paper points out that weak implementation has hampered the application of the EU law in Albania due to: a) weak bureaucracy or uneven distribution of human capacities; b) the lack of an established practice of consultation with interest groups on specific draft legislation, and c) the inability to put in sound planning mechanisms and to carry out a realistic assessment.

Throughout this study, a doctrinal research will be employed with the purpose to assess the impact that EU has had on the Albanian legal system. Relevant EU and Albanian legislation will be analysed in order, firstly, to address the current state of play of approximation and implementation process, and secondly, to point out main problems that have hampered the implementation process. Furthermore, secondary sources will be used throughout the paper. This paper does not include the assessment of the whole legislation vis-a-vis 35 chapters of EU acquis. Since there is no information on the percentage of the whole Albanian legislation approximated, the paper provides a general assessment of the importance of approximation process, how it works, the main actors involved and current situation of the approximated legislation relying on the documents released by Albanian government. Whereas, regarding the measuring of implementation process, the authors have relied on the annual EC Progress Report $2002-2016$ which serves not only to assess the preparedness of Albania to take on the obligations of membership but also to advise Albania on the 'main areas where efforts are still required'.[52]

The paper is structured as follows. The first section explains the aim, methodology and outline of the paper. The second section provides a theoretical approach of EU normative power and its usage as a normative legal power. The third section deals with the impact that the European Integration process has on Albania legal system through the obligation of Albania to approximate its existing and future legislation. The fourth section shed light on the actors involved in the approximation process, on the legal adaptation procedure and current situation of approximated legislation. The fifth section points out main problems encountered in the implementation process that put into question whether Albania has necessary institutional capabilities to ensure the implementation of approximated legislation. 


\section{Theoretical Approach: EU as a Legal Normative Power}

Until the 1970s, the idea to have a political union was premature considering the past experience on the European Defence Community where a supranational approach for foreign affairs was unacceptable for member states (Duke, 2010). In the Hague summit, held in 1969, head of states and government asked their foreign ministers to propose ways to achieve political union. One year later, a report came out proposing the creation of European Political Cooperation that satisfied the desire of France for stronger European voice in foreign affairs and would be accepted by Germany in order to redefine its position towards its eastern neighbours (Smith, 2014). Being separated from EC/EU framework, the European Political Cooperation goals were modest: regular consultation, coordination of national position, and where possible, common actions (Smith, 2014).

Since the establishment of European Political Cooperation, scholars started to be engaged on the nature of EC/EU and to what extent can EC/EU play a role in international scene. François Duchêne was the first author who coined EC/EU as a civilian power. According to him, "The European Community must be a force for the international diffusion of civilian and democratic standards or it will itself be more or less the victim of power politics run by powers stronger and more cohesive than itself" (Duchene, 1973). On the other hand, Hedley Bull - a pre-eminent English scholar in international relations - coined EC/EU as a military power (Hedley, 1982). Later on, in the 1980s the debate shifted on the actorness of the EC/EU to act in international relations (Hill, 1993). During 1990s, as a result of the several events that took place, the end of Cold War, enactment of Treaty on European Union that introduced political ambition of EC/EU to become a global actor, and wars in the Western Balkans countries, raised the interest of research to be focused on the "stateness" of EC/EU by using the concepts of "presence" and "international identity" (Manners, 1997).

A seminal article published in the Journal of Common Market Studies in 2002 by Ian Manners departed the debate of the nature of EU - civilian or military power - in the global politics (Manners, 2002). Manners, for the first time, developed the idea of normative power as the "ability to shape conceptions of 'normal' in international relations needs to be given much greater attention" (Manners, 2002). In this article Manners demonstrated that EU's normative basis stands on five 'core' norms - peace, liberty, democracy, rule of law and human rights - and on four minor norms -social solidarity, anti-discrimination, sustainable development, and good governance (Manners, 2002). Furthermore, Manners argued that the EU should be considered as a normative power, in order to extend its norms into the international system rather than the previous discourse characterizing EU in global politics as civilian or military power. According to 


\section{JOURNAL OF LEGAL STUDIES}

"Vasile Goldiș" Western University of Arad

him, there are six factors to the ways how EU norms are diffused in non EU countries. Respectively, the six factors are as follow: contagion, informational, procedural, transference, overt diffusion and cultural filter (Manners, 2002).

Once the idea of EU's normative power was conceptualized by Manners, it diffused into other normative framework. In his book, Youngs transforms the idea of normative power into the 'transformative power' (Young, 2004). At the same time, both Heather Grabbe (2004, 2006) and Mark Leonard (2005) in their work relied on the EU's normative power. In the following years, EU's normative power was studied in the legal context by asking to what extent the EU, through bilateral agreement and regional structures have influenced the domestic legal systems of third countries (Petrov, 2006, 2008; Magen, 2007). The main argument put forward by Magen (2007) and Petrov (2008) is that EU's transformative engagement exercised through different bilateral agreements is pushing these countries toward greater legal convergence to approximate their domestic legislation in compliance with the EU acquis.

Aspiration of Albania to join the EU entails the obligation to adjust its existing and future legislation in compliance with the EU acquis. Since Thessaloniki Summit in 2003 and the endorsement of the Stabilisation and Association Process as a driving strategy for the Western Balkan countries, Albania entered into more concrete action in terms of obligations steaming form European perspective [56] and more specifically Stabilisation and Association Agreement (SAA) [58]. The opening negotiation of the SAA was a starting point, with regard to the impact of the EU norms on the Albanian legal system. The Albanian government started to address the obligation to approximate existing and future legislation and to ensure proper implementation through adopting the National Plan for the Approximation of Legislation [70] and National Plan for the Implementation of the Stabilisation and Association Agreement [72]. It should be noted that both these national plans were adopted as the willingness of the Albanian government to advance with European Integration issues and not as an obligation per se. Once the Albania signed the SAA in 2006 and entered into force in 2009 , the obligation to approximate its legislation and ensure proper implementation was obligatory in advancing further for membership. The Albanian government translated the obligation steaming from SAA into the National Plan for the Implementation of the Stabilisation and Association Agreement [72], as last amended in 2017 [71]. In this way, through a top - down approach, the EU norms are penetrating into the Albanian legal system by obligating the Albanian government to approximate and ensure its proper implementation. 
3. Impact of the EU on the Albanian Legal system: The obligation to approximate its existing and future legislation

The Stabilisation and Association Agreement (SAA) falls under the mixed agreement or associate agreement where the "Union may conclude with one or more third countries or international organization agreements establishing an association involving reciprocal rights and obligations, common action and special procedure" [55] and represent the legal base between the candidate countries and the EU and the Member States in ex parte. The SAA aims to "provide the formal mechanism and the agreed benchmarks, which allow the EU to work with each country to bring them closer to the standards which apply in the EU" (Elbasani, 2008). Based on strict conditionality, SAA is a driving force for the WB countries toward European aspiration based on their own merits.

Albania signed the SAA in 2006 and it entered into force in April 2009 after ratification by all of the European Union Member states in accordance with their constitutional requirements. According to the Constitution of Albania adopted in 1998, as last amended in 2016 [53], international agreements constitute part of the internal legal system once they have been published in the Official Journal. In the case of SAA, as in other international agreements ratified by the Republic of Albania, any decision is binding upon signatory parties and is directly applicable after entering into force [53, art 122/1.] and has supremacy over domestic law [53, art 122/1.].

Approximation of domestic legislation with the EU acquis is one of the conditions for the accession of candidate states to the EU, confirmed by the European Council at the Copenhagen Summit in 1993. In this summit, the European Council decided that any European country wishing to join the EU had to meet the "acceptance of the Community acquis: ability to take on the obligations of membership, including adherence to the aims of political, economic and monetary union" [57]. According to Piontek, the approximation task "should mean an obligation to incorporate the respective Community rules in the legal order of the associated country to the fullest extent possible as an important condition of membership in the Union" (Piontek, 1997). Article 70 (1) of SAA stipulates that both parties "recognise the importance of the approximation of Albania's existing legislation to that of the Community and of its effective implementation" and "Albania shall endeavour to ensure that its existing laws and future legislation shall be gradually made compatible with the Community acquis". Therefore, approximation of laws has a particular importance for the candidate countries wishing to join the EU because they have to approximate domestic legislation with that of the EU.

Making reference to the words "approximation" and "shall endeavour" it can be concluded that the SAA provides a voluntarily harmonisation and does not mean an obligation for Albania to incorporate the acquis (Piontek, 1997). But in practice, 
endeavours clauses in article 70 (1) of SAA are a precondition for accession confirmed by the Copenhagen Summit and embodied in article 49 of TEU [54] stating that "the conditions of eligibility agreed upon by the European Council shall be taken into account". Therefore, despite the endeavours clauses, Albanian progress towards the EU membership depends on the approximation of domestic legislation and its effective implementation.

The SAA contains two categories of provisions on approximation. The first category are the horizontal provisions contained in Title VI "Approximation of Laws, Law enforcement and Competition rules" and the second category refers to the vertical rules on approximation contained in Title VIII "Cooperation Policies". The first category, horizontal provisions, can be regarded without doubt as the core of SAA (bushati, 2004). In addition, the horizontal provisions on the approximation of law arising from article 70 (1) of SAA have two major aspects. The first aspect is the adaptation of new legislation in compliance with the EU legislation. The second aspect deals with the proper implementation of this legislation. Both these aspects are equally important for applicant countries in terms of becoming members of the EU.

According to article 70 (2) - (3) of SAA, approximation process has to be carried out in two stages. During the first stage, starting from the date of signing of this agreement, approximation will focus on the fundamental elements of the internal market such as "competition, intellectual, industrial and commercial property rights, public procurement, standards and certification, financial services, land and maritime transport - with special emphasis on safety and environmental standards as well as social aspects - company law, accounting, consumer protection, data protection, health and safety at work and equal opportunities" [58]. While during the second stage, Albania has to focus its attention on the remaining parts of the acquis. Article 70 (3) (4) of SAA stipulates a detailed programme of the approximation process and modalities for the monitoring of the implementation of the approximation legislation and law enforcement actions to be agreed between the Commission and Albania.

The approximation process is a non-reciprocal process where the candidate country has to accept the entire obligation to approximate its domestic legislation to the EU (Karliuk, 2011). The scope of the approximation process "is defined by the regulatory extent of EU law and generally cannot be negotiated" Lazowski, 2002). The only thing left to candidate country to negotiate is the timetable of approximation process and the transitional period (Bushati, 2004). Therefore, the approximation process should not be understood as adopting a high quality legal text in certain areas, but rather as entailing the proper implementation and enforcement of the aligned legislation. 
4. Actors involved in the Approximation Process and Legal adaptation procedure

In order to cope with the requirement of the European Integration process to approximate domestic legislation, an institutional framework has to be established. The 2004 marks a pivotal moment for Albanian European integration. Firstly, a specific law was enacted with the purpose to regulate the role of Parliament on European Integration process. Secondly, the Ministry for European Integration was set up to deal with the integration process. It should be noted that until that time, all issues concerning the approximation process were managed by the department on the approximation of legislation with acquis under the Ministry of Justice (Vurno, 2008). As Dimitrova and Toshkov assert, "enlargement demands more efficient management of the preparation and negotiation process, which would be met by institutional adjustment, albeit ineffective or slow when administrative reforms are insufficient" (Dimitrovna, Toshkov, 2007). In the similar vein, Kellerman has argued that the approximation process is a complicated and demanding process that requires not only the adaptation of laws but also administrative capacities and other conditions to implement it (Kellerman, 2008). The following sections will explain: i) main actors involved in the approximation process (legislative and executive branches) and their functions; and ii) legal adaptation procedure for the approximation of domestic legislation. The section will conclude with current situation of approximation of Albania legislation.

\subsection{The role of Parliament and Committee for European Integration}

According to the Constitution of Albania, as last amended in 2016 [53], Parliament is the main and unlimited lawmaker in the approximation of domestic legislation. The first law that provided an explicit power to the Parliament on the European Integration issues was introduced in 2004 (Law 9252/2014) [58]. Despite being drafted with best European practices by reflecting tendencies of Assemblies of Centre East European countries, in 2015, a new law was enacted with the purpose to reinforce the role of the Parliament, as the highest law-making organ, in the European Integration process (Law 15/2015) [63].

Compared to the Law 9252/2004, the Law 15/2015 extended the scope of the Parliament's functions and clarified furthermore the institutional framework within the Parliament to deal with European integration issues. Accordingly, this law extends the scope of the Parliament on the functions relating with: i) monitoring and overseeing the implementation of legal framework; ii) monitoring and overseeing of allocations of financial instruments to support integration process and iii) increasing transparency by informing the public on the European integration process [63, art.3]. 
Whereas with regard to the institutional framework, the Law 15/2015 introduced two types of institutions: advisory institutions and permanent institutions. As advisory institutions, the Law 15/2015 set out National Council on European Integration which is assisted by the Technical Secretariat [63, art.8] and the Stabilisation and Association Parliamentary Committee lay down in the framework of SAA [68]. As the name shows, the main function of these types of institution is to advise Parliament on the issues of European integration. The National Council on European Integration is the highest advisory institutions, established within the Parliament, with the aim to promote and guarantee cooperation between different Albanian actors - political parties, public institutions, civil society - on European perspective of Albania and to assure the transparency on decision making for European issue. [63] In order to ensure this broadest scope, the National Council on European Integration is composed of various actors representing different interests. The National Council on European Integration is headed by the chairman of Committee for European Integration and comprises chairmen's and deputy chairmen's of Permanent Parliament Committees; representatives from parliamentary groups of Parliament; head of Albanian delegation of Stabilisation and Association Committee; ministry responsible for European Integration; representatives from chief of staff of President, Council of Ministers and Ministry for Foreign Affairs; General Prosecution; deputy chairman of High Council of Justice, Ombudsman and three members from civil society [63]. The fourth paragraph foresees as well, participation of the representatives from the Academy of Science and public universities; representatives from media, business and International Organizations. The other advisory institution, the Stabilisation and Association Parliamentary Committee [63], was established as a forum for members of the Albanian Parliament and European Parliament to meet and exchange views within the framework of Stabilisation and Association Agreement. The Stabilisation and Association Parliamentary Committee is presided in turn by the European Parliament and the Albanian Parliament, in accordance with the rules of procedures established by them.

The permanent institutions refer to the Committee for European Integration which is a permanent organ of Parliament established in accordance with article 18 of the Parliament regulation [61]. The main scope of the Committee for European Integration is related to: i) the approximation of laws with the EU acquis; ii) monitoring the obligations derived from SAA and iii) monitoring financial assistance given to Albania. In order to fulfil the above-mentioned objectives, the Committee for European Integration exercises the following responsibilities [63]. Firstly, the Committee for European Integration reviews - jointly with other parliamentary committees - draft laws related to the approximation of legislation with EU acquis. Secondly, the Committee for European Integration monitors: i) the 
implementation of the obligations arising from the EU accession process; ii) overall framework of negotiations for membership; and iii) jointly with the other Permanent Committees, the implementation of legislation Albanian aligned with the EU legislation. Thirdly, the Committee for European Integration promotes to the Ministry for European integration compilation and updating the national plan for European integration, as well as monitors its implementation. Fourthly, the Committee for European Integration coordinates the work with the Stabilization and Association Parliamentary Committee with the purpose to enhance cooperation with European Parliament bodies and, as well as parliaments of member countries of the EU. Finally, the Committee for European Integration cooperates with civil society organizations to provide information and ensure their participation in the European integration process.

\subsection{The role of the Council of Ministers, Ministry for European Integration and Line Ministries}

Executive branch has an important role in approximation of legislation. The main actors involved are: Council of Ministers; Ministry for European Integration and line ministries. The relations between the Council of Ministers and Parliamentary on the issues of European integration is stipulated in article 13 of the Law 15/2015 [53], which is more or less article 3 of the Law 9252/2004. According to article 13 of the Law 15/2015, the Council of Ministers, upon the request of the Parliament, informs the latter on the work done at various institutions of the EU, with specific reference to: a) draft agreements and conventions to be adopted in the framework of membership; b) draft acts dealing with commitments steaming from the European Union treaties, excluding administrative acts; c) draft acts steaming indirectly from the European integration process; and d) draft acts dealing with the use of the European Union funds.

Furthermore, compared with the Law 9252/2004, the new Law 15/2015 introduced specific provisions on the role of the Council of Ministers through: i) submission of the National Plan for European Integration in the Parliament (article 15); ii) submission of draft acts to be approximated (article 16) and iii) reporting on the situation of the Albanian and EU relations (article 18). Such vagueness left by the Law 9252/2004, may be argued with the inexperience in the approximation process and the most important, at that time, Albania was not obliged to deal with the approximation process since it had not yet signed the SAA. Pursuant to the Law $15 / 2015$, the Council of Ministers participates in the approximation process through submission of the National Plan for European Integration in the Parliament. Every year, a debate session on the task arising for the Parliament, is being held as provided in the National Plan for European integration and adopt resolutions on certain issues [53]. Furthermore, the Council of Ministers has the 
right to prepare and submit the updated draft list in order to schedule the agenda of Parliament and to determine the procedure for scrutiny [53]. It is responsibility of the Committee for European Integration to scrutinize the proposed updated draft list and jointly with other Permanent Committees, prepare a special report with recommendation that shall be forwarded to the Council of Ministers [53]. Finally, by the end of January of each year, the Council of Ministers submits to the Parliament a detailed report on: i) the fulfilment of obligation foreseen in the National Plan for European Integration, ii) 'state of play' of negations between the EU and Albania and iii) the management of the EU fund and other donors for the previous year [53]. The report is discussed in a plenary session and in the end, Parliament approves the resolutions. Additionally, after the release of the EC Progress Report, the Council of Ministers has the duty to report on the Parliament the findings, recommendations and commitment to address the recommendation laid down [53].

Another institution that has an important role in the approximation process is the Ministry for European Integration, established in 2004 with the Decision of the Council of Ministers (DCM) no 580 [69]. Until that time, all issues relating to the European integration process were covered by the Ministry for Foreign Affairs. The prospect of membership given at Thessaloniki Summit (2003) enabled the Albanian government to set up an institution at the level of ministry with the purpose to: ensure technical guidance and coordination of the integration process of the Republic of Albania in the European Union, through the approximation of national legislation to EU law and drafting of integration policies, coordination of financial assistance and public information in this process [69].

In 2013, a new DCM 946 was enacted, repealing the previous one. According to DCM No 946/2013 "On the scope of Ministry of European Integration", the Ministry for European Integration performs 4 types of activities. Firstly, the Ministry for European Integration coordinates and monitors preparation of Albanian institutions in their efforts to meet commitment in the framework of SAP. Secondly, the Ministry for European Integration develops the National Plan for the Implementation of the SAA and methodologies to facilitate implementation of sector reforms required under the SAA. Thirdly, the Ministry for European Integration assesses the compliance of legislation proposed by line ministries and other central institutions to the EU acquis and certifies translation of the basic documentation required for the approximation of the national legislation. And fourthly, the Ministry for European Integration participates in working groups set up by Government for developing programmes for integration issues and exchanges information and organises regular meetings at national, regional and international level in the context of the EU integration process [75]. 
Finally, Line Ministries were established in 2006 [71] with the purpose to assist main ministries in the approximation process. In 2015, the Council of Ministers enacted a new decision "For the establishment of the Network of European Integration Units and the Network of Drafting legislation in Line Ministries" [65]. As the title shows, two units were established with different functions. Accordingly, each Ministry will have the European Integration Units responsible to maintain relations with other units and Ministry of European Integration within the framework of obligations deriving from SAA. Whereas, the Units for Drafting Legislation is responsible only in drafting process and assessing whether draft acts are in compliance with the EU acquis or not.

\subsection{Legal adaptation procedure}

After having laid down the institutional framework for the approximation process it is important to explain how the process proceeds. The Council of Ministers is the promoter of the approximation process. The modus operandi of Council of Ministers in matters regarding drafting and proposing acts is foreseen in the Regulation of Council of Ministers, as last amended in 2015 [64]. The amendment brought several novelties in the area of EU integration. Firstly, the draft program of the acts submitted by each ministry, within December of each year, for the next meeting of the Council of Ministers, has to be coordinated with the National plan for European Integration that aims to adjust domestic legislation in compliance with the acquis [64]. Secondly, acts that are proposed pursuant to implementation of the National Plan for European Integration, have to be accompanied by a concordance table that enables line ministries and other agencies to identify the level of approximation [64]. Furthermore, the draft submitted for opinion implementing the National Plan for European Integration must be accompanied by concordance table and as well by the legal act of the European Union, which is supposed to be approximated, translated into Albanian [64]. Thirdly, the consent of the Ministry of European Integration is obligatory for issues related to the approximation of legislation. Draft acts have to be accompanied by table of concordance and the level of approximation. Once the draft acts have been prepared, the Council of Ministers, every January of each year, submits to the Parliament an updated list of draft acts to be included in the agenda of the Parliament [63].

The assessment of draft laws whether are in compliance with the EU legislation is carried out by the Committee for European Integration and other Permanent Committee based on their area of expertise [63]. Every draft law proposed by the Council of Ministries or Line Ministries has to be accompanied by a concordance table and a report that complies with the requirements laid down in the Albanian Parliament Regulation for legislative process [61]. According to article 68 of this 
procedure, draft laws must be designed as formative acts and must attach a report that foresees: objectives to be achieved; possible arguments against these objectives being achieved with the current legal instruments; the compliance of the draft law with the constitution and the EU legislation, as well as its social and economic effects [61]. In the case where the draft laws are not completed properly by the respective institutions, the bodies of Parliament have the obligation to return the draft act for adequate completion and to be resubmitted in the Parliament within 15 days. According to article 17 (4), the Ministry for European Integration will establish a database for concordance table that has to be updated by the institutions that have the right to propose laws. Institutions that have proposed the changes have the obligation to reflect changes, after 15 days since the law has been published in the Official Journal.

With the entry into force of the Stabilisation and Association Agreement (2009), the Albanian government has adopted several national plans to address the obligations arising from the EU membership. Generally, Albania has made progress in aligned the domestic legislation [49]. In many areas, progress has been made to bring domestic legislation in compliance with the EU acquis. Lately, on 31 January 2017, the Council of Minister adopted the National Plan for European Integration for the period 2017 - 2020 [78]. The National Plan for European Integration 2017 - 2020 set out short and medium legal measures to be taken with the final aim that by 2020 Albania must fully align its legislation with the acquis of the EU and meet the standards of the acquis chapters. Despite the strong ambition to bring the whole domestic legislation in line with the EU acquis - as it was set out in the National Plan for European Integration 2017 - 2020 - the 2016 EC Progress Reports pointed out that the Albanian government must address not only bringing the legislation in compliance with the EU acquis but also ensuring proper implementation of the adjusted legislation [78].

\section{Lost in Implementation: Not an easy task}

In public administration, the implementation process is defined as "what happens after a bill becomes a law" (Bardach, 1977) or, put differently as, "translating laws and decrees made by politicians into action" (Peter, Pierre, 2012). This is because certain laws adopted by government will not be implemented automatically unless these laws are managed effectively by the public bureaucracy. In the context of the EU enlargement, Ulf Sverdrup defines implementation as "processes through which European norms are transposed, adhered to and enforced at the domestic level" (Sverdrup, 2008), while Christoph Knill defines implementation effectiveness as "as the degree to which the formal transposition and the practical application of supranational measures at the national level correspond to the objectives defined in European legislation" (Knill, 1998). Two conclusions can be 
derived from the above definitions. Firstly, the EU acquis is not negotiable and Albania shall implement what is offered by the EU even in the case where there is a clash between EU norms and domestic ones. The latter have to be in compliance with the EU norms. Secondly, and most importantly, implementation has to be done by the administration of the aspirant countries. This means that the administration plays a crucial role in the European Integration process and especially in the implementation of the EU norms. The White Paper adopted in 1995 warned that: The main challenge for the associated countries in taking over internal market legislation lies not in the approximation of their legal texts, but in adapting their administrative machinery and their societies to the conditions necessary to make the legislation work [51].

Thus, if an administrative body lacks human resource capacities or if it does not have enough experience, the implementation process will be mismanaged. In this context, two important questions will be addressed: why does the implementation of laws matter in the European integration process, and what problems have Albania encountered in this process?

The implementation process is important because it determines two issues. Firstly, to what extent the EU as a transformative power in affecting the domestic legal system and, secondly, to what extent the applicant countries are willing to implement European norms. Regarding the issue of transformative power, the EU, through conditionality, is exerting its power and diffusing its norms in an unprecedented way. Applicant countries (in our case Albania) are not able to pick or choose those parts of the acquis they desire. As been acknowledged by previous enlargement, the beauty of the acquis is that it is not negotiable between parties. Parties can negotiate on the time needed or manner of harmonisation but not for the essence of the acquis because the accession of applicant country is conditioned by acceptance of all the rights and obligations the EU is grounded on.

In general, Albania has developed a modern legal framework in compliance with the acquis, but the problem remains implementation due to: a) weak bureaucracy or uneven distribution of human capacities; $b$ ) the lack of an established practice of consultation with interest groups on specific draft legislation, and c) the inability to put in sound planning mechanisms and to carry out a realistic assessment.

\section{a) Uneven Distribution of Human Resources}

In their study, Peter Hille and Christoph Knill analyse the implementation of the acquis in EU candidate countries during 1999 - 2003. They conclude that 'the implementation of the acquis communautaire in candidate countries prior to accession has been a question of bureaucratic problems rather than political vetoplaying' (Hille, Knill, 2006). They argue that besides having sufficient financial resources for the bureaucracy, the implementation process also depends on the 
strength of bureaucracy, translated as: a) the independence of the administration from politics; b) a clearly specified legal framework for the bureaucracy, and c) the accountability of the bureaucracy as a crucial factor that contributes towards its own quality and effectiveness (Hille, Knill, 2006).

Whereas, Dimitri A. Sotiropulos, in his study, finds out that the public bureaucracies of Southern Europe (Greece, Italy, Portugal and Spain) until mid of 1990's were characterised by interrelated characteristics such as: a) party politicians working in higher civil service; b) patronage patterns of personnel recruitment to the public sector; and c) lack of human resources in the public sector and lack of implementation (Sotiropoulos, 2004). In contrast to the Central and Eastern European Countries where the implementation of the acquis has been a question of bureaucracy rather than political veto, in the case of Albania, both factors have been influential.

As in Southern Europe, Albanian bureaucracies suffer from the political appointment of higher civil servants and senior and mid - level civil servants [44]. Since 1992, governmental changes have been associated with politicised nomination in public administration (Blendi, Bumçi, Rakipi, 2002). For example, during the period 1992 - 1997 Miranda Vickers and James Pettifer noted that public officials "had their biographies scrutinised so that grounds could be found for dismissing them in favour of Democratic Party loyalists and northern clansmen" (Pashaj, 2010). Another example is the interview of the previous Minister of Health given to a private television station. He argued on television that in order for the coalition with the Democratic Party to make sense and work, people from his political party had to be represented in the ministry that he ran (Methasani, 2009). This argumentation reveals the political parties interference in public administration.

The politicisation of the public administration in Albania has occurred in three ways a) the hiring of public officials with contracts rather than using competitive exams as the law requires; b) the right of ministers to reshuffle the structure of ministries, and c) the discretion used by the Department of Public Administration to select one of the three shortlisted candidates for the position (Pashaj, 2010). This in turn has brought uneven distribution of the human capacities based on the political affiliation and has undermined the efficacy and legitimacy of institutions. There is no official data on politically motivated dismissals affecting public administration or on whether the public sector is overstaffed. Too often, government changes have been associated with dismissal of key experts in the Ministry for European Integration and in EU line ministries, based on political affiliation, and their replacement with political party members (Lumezi, 2013). This politicisation of bureaucracy has brought "the absence of sound accountability mechanisms in public administration [which] increases the opportunities for 
bypassing established procedures" [46]. According to the EC Progress Report of 2012, bureaucracies "suffer from shortcomings related to politicisation and a lack of meritocracy in recruitment, promotion and dismissal of civil servants" [47].

Another factor influencing implementation relates to the commitment of political parties to cope effectively with the EU requirements on strengthening the administrative capacities [50]. Unfortunately, due to the lack of political party cooperation to adopt laws set out in 2010 EC Progress Report (12 priorities), especially the Civil Service Law, the candidate status of Albania was postponed. In May 2013, the Albanian Government adopted a new law on Civil Service Law and its foreseen date for entering into force was October 1st, 2013. However, due to some technical problems in the new government led by the Socialist Party, this was postponed by 6 months. This law, one of the priorities required by the Commission to obtain candidate status, was a major measure to de-politicise the public bureaucracy and to "build a professional, effective and merit-based public administration" [48].

\section{b) Lack of Wide Consultation}

Public consultation is a process that requires involvement of interest groups during the preparatory and adoption phase which aims to increase transparency in the decision - making and the quality of the law. The 2013 EC Progress Report points out that the process of approximation of legislation with the acquis is accompanied by the ineffective implementation of legislation. The reports states that: Weak analytical capacity and high staff turnover in line ministries, together with insufficient transparency and consultation with relevant stakeholders, continue to hamper the legislative drafting process. [48]

In only one sentence, the Commission report describes two key deficiencies of Albania's approximation process. These deficiencies have an impact on the quality of laws drafted. In a study carried out by the Institute for Democracy and Mediation for the period January - December 2010, the two active parliamentary committees for the alignment process - the Committee on Legal Issues and the Committee on Economy and Finance - revealed that no private sector interest group attended the meetings. The Parliamentary Committee on Economy and Finance held 71 meetings in total from January - December 2010, and no civil society or interest groups participated or attended. While, in the Parliamentary Committee on Legal Issues, out of 88 meetings only on two occasions civil society groups were invited to discuss the special draft legislation [67]. Whereas another survey conducted by the Institute for Democracy and Mediation for the Parliamentary Committee for European Integration, for the period September 2008 - September 2010, showed that civil society was invited to a hearing of the Committee only once, to discuss the draft law on the discrimination [66]. As can be 
seen from these two examples, Parliamentary Committees hearings lack proper consultation with interest groups.

To address the lack of public participation, on 30 October 2014, the Albanian Parliament adopted the Law 146/2014 "On Public Notification and Consultation". The scope of this law was to regulate the process of notification and public consultation of draft laws, national and local strategic drafts, as well as policies with high public interest [62]. It established procedural rules to be followed aiming to ensure transparency and public participation in policy - making and decision making processes of public bodies. The law entered into force at six months after having been promulgated in the Official Journal (May 2015).

However, since the law entered into force, the level of implementation is unsatisfactory. 21 months have passed since the enactment of the law and still, the Electronic Registry for public notification and consultation is not functional. According to article 7 of the Law 146/2014, the Electronic Registry was designed to be a focal point for consultation, where all stakeholders would have access and opportunity to communicate with public bodies. Although, the law provides other alternative ways for notification and consultation of draft laws and national and local strategic document (article 6), the establishment of Electronic Registry would increase the public participation and interested stakeholders in discussion and decision making. This in turn, will improve the level of enforcement.

Furthermore, the Law 15/2015 has increased the engagement of interest groups in consultation and policy development during the legislative drafting process [63]. One article has been asserted stipulating the relation between Parliament and civil society. Accordingly, the Committee for European Integration and other Permanent Committees are obliged to invite civil society during: i) hearing process related to European Integration and ii) adopting a legal framework aimed at approximation of legislation [63]. Additionally, the Committee for European Integration may convene public meeting with civil society to discuss issues related to European Integration [63]. Within this framework, civil society representatives have participated in meetings of the National Council of European Integration or Committee for European Integration, but their role has remained passive overall. As 2016 EC Progress Reports stipulates "effective implementation of the laws on the right to information and public consultations remained a challenge" [49]. Therefore, the Line Ministries and Parliamentary Committees must consult widely with interest groups.

\section{c) Sound Planning Mechanisms}

As it has been explained, any draft legislation deems to fail if it is not implemented properly by the stakeholders. Therefore, the implementation process depends on the willingness of stakeholders in the integration process. Besides the weakness of 
civil society to influence decision-making in the drafting process and its implementation [43], the implementation also depends on the political will to provide a sound planning mechanism to carry out a realistic assessment on the impact of laws in terms of the infrastructure necessary for implementation. According to 2010 EC Progress Report: Proper implementation of, and respect for, legislation have been affected by its poor quality. Furthermore, implementation is hampered at times by the lack of full understanding of the social and political role of laws by relevant public sector institutions; these disregard certain legal provisions as a result. There have been cases in which respect for legislation and the rule of law have been put into question by the government, with Constitutional court decisions and rulings being challenged or even disregarded. [50]

Max Weber, the father of modern sociology, argues that a law is rational when it reflects social, economic and political needs and is adopted and implemented through procedural rules (Deflem, 2008). Thus, when a law is adopted, a good understanding is required of the situation and the law's impact and implementation needs. If the law does not reflect social, economic and political needs and is not implemented with a realistic assessment of the institutional and infrastructure capacity, then the law is deemed to have failed in its implementation. An example of this is the Anti-Smoking Law [73] (DCM, 2006) and the Law on Environmental Impact Assessment [59]. Both laws have not been implemented due to the lack of the consultation with stakeholders in terms of an impact assessment and the necessary infrastructure. Another example is the Civil Service Law which was adopted in May 2013 by the former government and whose entry into force date was postponed by 6 months, with the argument that the law had not foreseen an institutional structure or the financial effects on the budget for its implementation [60]. Once again, political will is a determining factor in the adaption and proper implementation of laws.

\section{Conclusion}

The key objective of the enlargement policy toward Albania is the gradual diffusion, institutionalisation of formal and informal rules characterising EU policy and politics and then incorporating into the Albanian legal system. The main instrument and condition to achieve legal adjustment is Albania's approximation to the EU acquis. So far, European integration process has pushed Albania towards greater convergence with the EU acquis through developing a modern legal framework. Despite, financial assistance given by the EU under different instruments - CARDS; IPA I and IPAII - and legal assistance under different stakeholder commissioned by EU, Albania's progress toward adjusting its legislation remains unsatisfactory. Approximation of existing and future legislations, generally, is in compliance with the required standards, but ensuring 
its proper implementation remains daunting for Albania. The various EC Progress Reports have underlined the particular problems that Albania faces in the process of approximation and application of the EU law due to: a) weak administration bureaucracy or uneven distribution of human resources; b) the lack of an established practice of consultation with interest groups on specific draft legislation, and c) the inability to put in sound planning mechanisms and to carry out a realistic assessment.

In conclusion, the effective adjustment of the Albanian legal system with the EU norms requires cooperation between actors involved in the approximation and the implementation process. This is essential for the advance of Albania towards the EU integration. Otherwise, if there is no close cooperation between actors during drafting process of legislative acts, Albanian integration will be impossible.

\section{References}

1. Bardach, E. (1977), The Implementation Game: What Happens after a Bill Becomes a Law, MIT Press, Cambridge, 1977.

2. Bideleux R., Jeffries J. (2004), the Balkans: A Post-Communist History, Routledge, Abington.

3. Börzel, T. (1999), "Towards Convergence in Europe? Institutional Adaptation to Europeanisation in Germany and Spain" Journal of Common Market Studies vol. 37, pp. $573-596$.

4. Bretherton C., Vogler, J. (1999), The EU as a Global Actor, $2^{\text {nd }}$ edition Routledge, London.

5. Bull, H. (1982), "Civilian Power Europe: A Contradiction in Terms?", Journal of Common Market Studies, pp. 149-164.

6. Bushati, D. (2004), "Approximation of the Domestic Legislation to the Community Acquis as a Prerequisite for the EU Integration", $<$ http://www.westernbalkans.info

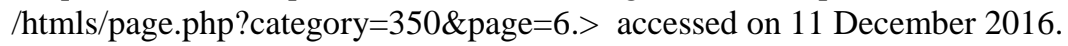

7. Deflem, M. (2008), Sociology of Law: Visions of a Scholarly Tradition, CUP, Cambridge.

8. Dimitrova A., Toshkov, D. (2007), "The Dynamics of Domestic Coordination of EU Policy in the New Member States: Impossible to Lock In?", West European Politics, pp. 961-986.

9. Duchêne, F. (1973), "The European Community and the Uncertainties of Interdependence", In Max Kohnstamm, and Wolfgang Hager, (eds) A Nation Writ Large? Foreign Policy Problems before the European Community. Macmillan, Basingstoke.

10. Duke, S. (2010), The Elusive Quest for European Security: From EDC to CFSP, Palgrave, Basingtone.

11. Elbasani, A. (2008), "The Stabilisation and Association Process in the Balkans: Overloaded Agenda and Weak Incentives?" $<$ http://cadmus.eui.eu/bitstream 
/handle/1814/8447/SPS_2008_03.PDF;jsessionid=1DCFD39461303F80AFBA785FA C9CEE78? sequence $=1 .>$ accessed on 11 November 2016.

12. Elbasani, A. (2009), "EU Administrative Conditionality and Domestic Downloading: the Limits of Europeanization in Challenging Context" $(2009)<\mathrm{http}: / / w w w . p o l s o z . f u-$ berlin.de/en/v/transformeurope/publications/working_paper/WP_02_July_Elbasani.pdf ?1367706571.> accessed 18 November 2016.

13. Grabbe, H. (2004a), The Constellations of Europe: How Enlargement will Transform the $E U$, Centre for European Reform, London.

14. Grabbe, H. (2004b), The EU's Transformative Power: Europeanisation through Conditionality in Central and Eastern Europe, Palgrave, Basingstoke.

15. Green Cowles M., Caporaso J., Risse T. (eds.) (2001), Transforming Europe: Europeanization and Domestic Change, Cornell University Press, Ithaca.

16. Hill, C. (1993), "The Capability-Expectations Gap, or Conceptualizing Europe's International Role", Journal of Common Market Studies, pp 305-328.

17. Hille P., Knill, C. (2006), "It's the Bureaucracy, Stupid: The Implementation of the Acquis Communautaire in the EU Candidate Countries, 1999-2003", European Union Politics, pp. 531 - 552.

18. Kajsiu, B., Bumçi, A., Rakipi A. (2002), Albania - a Weak Democracy a Weak State, Albanian Institute for International Studies, Tirana,.

19. Karliuk, M. (2011), "EU and Third Countries: Legal Approximation Methodology", <http://praunik.majstar.com/en/artykuly/173> accessed on 14 December 2016.

20. Kellerman, A. (2008), "Procedures for the Approximation of Albanian Legislation with the Acquis Communautaire", in C Stefanou and H Xanthaki, (eds) Drafting Legislation: A Modern Approach. Ashgate, England.

21. Knill, C. (1998), "European Policies: The Impact of National Administrative Traditions", Journal of Public Policy, pp. 1 - 28.

22. Ladrech, R. (1994), "Europeanization of Domestic Politics and Institutions: The Case of France" Journal of Common Market Studies, vol. 32, 1994 pp. 69 - 88.

23. Lazowski, A. (2002), "Approximation of Laws" in Andrea Ott and Kirstyn Inglis, (eds) Handbook on European Enlargement: a Commentary on the Enlargement Process. T.M.C. Asser Press, The Hague.

24. Leonard, M. (2005a), "Europe's transformative power" <http://www.cer.org.uk/publications/archive/bulletin-article/2005/europestransformative-power $\geq$ accessed on 12 December 2016.

25. Leonard, M. (2005b), Why Europe will run the 21st century, Fourth Estate, London.

26. Lumezi, A. (2013), "Resigned Official Çiço: Laws and Orders are being Ignored in the Recruitment of Staff" < http://illyriapress.com/dorehiqet-sekretarja-e-pergjithshme-eintegrimit-cico-po-injorohen-ligjet-dhe-urdhrat-ne-rekrutimin-e-stafit/> accessed on 1 December 2016.

27. Magen, A. (2007), "Transformative Engagement Through Law: The Acquis Communautaire as an Instrument of EU External Influence" European Journal of Law Reform, pp. 361-392.

28. Manners, I. (1997), "The International Identity of the European Union: Its Internal Construction" presented to panel on Explaining the International Identity of the 
European Union, convenors: Richard Whitman and Ian Manners, Loughborough University, UACES Annual Research Conference, September 1997.

29. Manners, I. (2002), "Normative Power Europe: A contradiction in Term?", Journal of Common Market Studies, pp. 235-258.

30. Methasani, E. (2009), "Civil Service and its Implications by Political Changes: the Case of Albania", $17^{\text {th }}$ NISPAcee Annual Conference, Budva.

31. Pashaj, (2010), "Civil Service Reform in Albania: The Broken Promise of DePoliticisation", M. A. in Public Policy Thesis, Central European University, Budapest.

32. Peter, B.G, Pierre, J. (2012), "Introduction: The Role of Public Administration in Governing" in B Guy Peter and Jon Pierre (eds), The SAGE Handbook of Public Administration, SAGE Publications Ltd., London.

33. Petrov, R. (2006), "The Dynamic Nature of the Acquis Communautaire in EU External Relations", European Review of Public Law, pp. 741-771.

34. Petrov, R. (2008), "Exporting the Acquis Communautaire into the Legal Systems of Third Countries", European Foreign Affairs Review, pp. 33-52.

35. Piontek, E. (1997), "Central and Eastern European Countries in Preparation for Membership in the European Union - a Polish Perspective", Yearbook of Polish European Studies, pp. 73 - 87.

36. Radaelli, C. (2003), "The Europeanization of Public Policy” Kevin Featherstone and Claudio M Radaelli (eds.), The Politics of Europeanization, Oxford University Press, Oxford.

37. Sedelmeier, U. (2014), 'Europeanization' in Erik Jones, Anand Menon and Stephen Weatherill (eds), The Oxford Handbook of the European Union. OUP, Oxford.

38. Smith, K. (2014), European Union Foreign Policy in a Changing World, Polity, Cambridge.

39. Sotiropoulos, D. (2004), "Southern European Public Bureaucracies in Comparative Perspective", West European Politics, pp 405 - 422.

40. Sverdrup, U. (2008), "Implementation" in Paolo Graziano and Marteen P Vink (eds), Europeanization: New Research Agendas, Palgrave, Basingstoke.

41. Vurno, G. (2008), "Relations of Albania with the EU", (Paper presented in the Framework of the Project: 'Integration Perspectives and Synergic Effects of European Transformation in the Countries Targeted by EU Enlargement and Neighorhood Policies', Center for EU Enlargement Studies.

42. Youngs, R. (2004), "Engaging: sharpening European influence. In New terms of engagement", In Richard Young. (ed) Global Europe Report 2: New Terms of Engagement, The Foreign Policy Centre, London.

43. Commission, "Albania: Stabilisation and Association Report 2004" (Commission Staff Working Paper) SEC (2004) $374 / 2$.

44. Commission, "Albania: 2006 Progress Report" (Commission Staff Working Document) SEC (2006) 1383.

45. Commission, "Albania: 2007 Progress Report" (Commission Staff Working Document) SEC (2007) 1429.

46. Commission, "Albania: 2008 Progress Report" (Commission Staff Working Document) SEC (2008) 2692. 
47. Commission, "Albania: 2012 Progress Report" (Commission Staff Working Document) SWD (2012) 334.

48. Commission, "Albania: 2013 Progress Report" (Commission Staff Working Document) SWD (2013) 414 final.

49. Commission, "Albania: 2016 Progress Report" (Commission Staff Working Document) SWD (2016) 314.

50. Commission, "Commission Opinion on Albania's application for Membership of the European Union" (Commission Staff Working Document, Analytical Report) SEC (2010) 1335.

51. Commission, "Preparation of the Associated Countries of Central and Eastern Europe for Integration into the Internal Market of the Union" (White Paper) COM (1995) 163 final.

52. Commission, Understanding Enlargement: The European Union's Enlargement Policy, Directorate General for Enlargement, Brussels, 2011.

53. Constitution of the Republic of Albania 1998 as amended last on (2016) [138].

54. Consolidate Version of Treaty of the European Union (TEU) [2010] OJ C83/53.

55. Consolidate Version of Treaty on the Functioning of the European Union (TFEU) [2010] OJ C83/53, art 217

56. Council Regulation (EC) 533/2004 of 22 March 2004 on the Establishment of Partnerships in the Framework of the Stabilisation and Association Process [2004] OJ L 86/1.

57. European Council, "Conclusion of the Presidency" (2003) <http://www.consilium. europa.eu/ueDocs/cms_Data/docs/pressData/en/ec/72921.pdf > accessed on 11.12.2016

58. For the work of Parliament on the European Integration process of Albania in EU Law (2004) [9252] OJ 53

59. For some Changes on the Law No. 8990/2003 on Environmental Impact Assessment DCM (2008) [10050].

60. For some Changes on the Law No. 152/2013 for Civil Service DCM (2013) [5].

61. For some changes and supplement on Parliament Decision no 166 date 16.12.2004 "For approval of the Regulation of the Parliament of the Republic of Albania" Decision of Parliament (2014) [95] OJ 189.

62. For Notification and Public Consultation Law (2014) [146] OJ 178.

63. For the role of Parliament on the European Integration process of Albania in EU Law (2015) [15] OJ 38.

64. For some supplement and changes in decision no 584 of date 28.08.2003 of Council of Ministers "For Approval of the Regulation of Council of Ministers" as amended DCM (2015) [223] OJ 43

65. For the establishment of the Network of European Integration Units and the Network of Drafting legislation in Line Ministries DCM (2015) [577] OJ 166

66. Institute for Democracy and Mediation, "Three "Steps" to Improve Parliamentary Dealings on EU Accession”, Policy Brief no. 5, IDM, Tirana, 2010.

67. Institute for Democracy and Mediation, "Lost in Implementation: Albania's Alignment with the EU Acquis", Policy Brief no. 2, IDM, Tirana, 2011. 
Hajdini, B., Skara, G. (2017)

Lost in Implementation: EU Law Application in Albanian Legal System

68. Stabilisation and Association Agreement between the European Communities and their Member States, of the one part, and the Republic of Albania, of the other part Protocols - Declaration (SAA) [2009] OJ L 107/166.

69. On the Scope of Activity of the Ministry of European Integration DCM (2004) [580] OJ 65.

70. On Approval of National Plan for the Approximation of Legislation DCM (2005) [317].

71. On the Establishment of European Integration Units in Line Ministries DCM (2006) [179] OJ 32.

72. On Approval of National Plan for the Implementation of the Stabilisation and Association Agreement DCM (2006) [463].

73. On the Protection of Public Health from Tobacco Products Law (2006) [9636].

74. On approval of the National Plan for the Implementation of the Stabilisation and Association Agreement, 2012 - 2015 and determination of institutions' responsibility for approximation of Albanian legislation with the European Union legislation DCM (2012) [486].

75. On the Scope of Activity of the Ministry of European Integration DCM (2013) [946] OJ 167.

76. On approval of National Plan for European Integration 2014 - 2020 DCM (2014) [438].

77. On approval of National Plan for European Integration 2015 - 2020 DCM (2015) [404].

78. On approval of National Plan for European Integration 2017 - 2020 DCM (2017) [12].

79. 2005 